\title{
Handicraft in the Context of Sustainable Education
}

DOI: 10.22616/REEP.2018.036

Iveta Lice-Zikmane Dr. paed.

Latvia University of Life Sciences and Technologies, Latvia

iveta.lice@1lu.lv

\begin{abstract}
Each century brings something new and unprecedented to the characterization of the era. It has its own values and the view of the world. The 21 st century is characterized by rapid changes in economics, politics, and the development of different technologies. The young person comes into the social environment with other interests and desires, with high demands, with activity and competitiveness. Human values are changing as well. It is a challenge for education, its product, for the education of a new person, for sustainable thinking and action. The public opinion is turned to the sustainable development of the society. There is much debate about the education for sustainable development. The competences and learning habits acquired at school are essential for developing new skills for new jobs later in life. The change of paradigm in education also involves the change of teachers' and students' competences. The development of an up-to-date educational content and approach takes place in Latvia, too. Home Economics and technologies is one of the subjects at school, where education for sustainable development is carried out. Home economics and technologies deals with various topics related to sustainable development. One of those topics is „Handicraft”. The teaching and learning process in handicraft lessons is being looked through the point of view of education for sustainable development. Handicraft as a handmade product is a popular household object. Handicraft is acquiring another value compared to industrially made mass production goods. The aim of the research is to determine the students' attitude towards handicraft. The research methods such as questionnaires and discussions were used in the current investigation. The place of the research: Jelgava, Latvia. Altogether 255 respondents take part in this investigation. Results show a variety of respondents' groups. The obtained results reveal that respondents mainly like to wear, use handicraft products, that handicraft is respected in families. The results of the questionnaire convincingly show that the theme Handicraft must be included in the curriculum. It is shown by the majority of the respondents from all the groups.
\end{abstract}

Keywords: handicraft, home economics and technologies, sustainable education, school education.

\section{Introduction}

The changes in one sphere of life carry along some changes in other spheres. The prosperity of the national economics promotes the human personality growth opportunities, the broadening of his/her comfort zone that provides an ascending quality of life. The human being is the one who stands close by the challenges of nature and technologies. It is a challenge for him/her as for the most developed living being on the Earth. Being together with nature, taking care of it and profiting from it at the same time. Human values are changing as well. The public opinion is turned to the sustainable development of the society.

The basic idea of sustainable development invites to satisfy the needs of the present generation, balancing public welfare and environmental and economic development interests and concurrently ensuring the observation of the environmental requirements and the preservation of natural diversity in order to avoid the reduction of possibilities to satisfy the needs of future generations, indicated in document Sustainable Development Strategy of Latvia until 2030 (Sustainable Development Strategy..., 2010).

We live in a rapidly changing and increasingly interdependent world where knowledge and innovation are major drivers of development. This means good quality education and learning are becoming even more important determinants of the well-being of individuals, the progress of countries and the quality of humanity's common future (UNESCO, 2014). The main strategic principles can essentially increase the opportunities of the sustainable development of Latvia and they are defined considering the global tendencies and evaluating the resources of Latvia and its utilization. These are:

- creative work;

- tolerance;

- co-operation;

- participation (Sustainable Development Strategy..., 2010). 
The report of the Commission of the European Communities indicates that the European Council has repeatedly drawn attention to the key role of education and training for the future growth and long-term competitiveness of the Union. It is important to achieve this to fully develop the potential for innovation and creativity of European citizens, and this should be strengthened at an early age - at schools. The competences and learning habits acquired at school are essential for developing new skills for new jobs later in life (Commission of the European..., 2008).

The change of paradigm in education also involves the change of teachers' and students' competences. An Agenda for European Cooperation on Schools indicate 3 areas improving competences for the 21 st century:

- focus on competences;

- high quality learning for every student;

- teachers and school staff (Commission of the European..., 2008).

During the period covered by this strategy, the education sector as a whole will need to respond to increasingly complex, rapid and often unpredictable developments beyond the sector itself (UNESCO, 2014). Change of paradigm in education, providing for closer link of educational system with economic and public processes, also change the nature of work of teachers. A teacher should be not only the teacher of his or her study subject, but also a diverse, talented personality who helps, inspires, joins different fields, co-operates, gives advices and organises (Sustainable Development Strategy..., 2010).

To acquire competences, learners need, from an early age, to 'learn to learn' by reflecting critically on their learning aims, managing their learning with self-discipline, working autonomously and collaboratively, seeking information and support when necessary, and using all the opportunities of new Technologies (Commission of the European..., 2008).

Based on the above-mentioned documents, the development of an up-to-date educational content and approach takes place in Latvia too. It is necessary to improve the basic skill acquisition of children and adolescents in significant spheres of human activity. „Nowadays children need to learn to live in the world that is continuously changing, and they must be ready to create a so far unknown economic, politic, social and cultural environment”, pointed out in „Education for modern competence: the description of approach for education content" (Skola 2030, 2017, 5).

The aim of the improved education content and approach is a competent pupil who wants to learn and is able to learn all life long, who can solve real life challenges, create innovations, acquire different personality traits that help him/her develop into a happy and responsible person. The foundation of the new content is based on the basic principles: succession, regularity and integrity. Whereas the education content is formed by virtue, transversal skills, understanding and basic skills (Skola 2030, 2017). To provide a modern education for each pupil it is significant to improve the approach for education within the curriculum, strengthening the shift of accents from giving students complete knowledge to guiding their learning process where they learn in depth. The teacher:

- puts forward clear and meaningful achievable results;

- offers multiform, complex, personally important tasks in the learning process that give a chance to create an actual understanding, to connect things learned in the process, that stimulates to choose the most suitable problem-solving methods;

- provides suitable support and regular feedback during the learning process;

- encourages students to reflect their learning and thinking (Skola 2030, 2017).

Home Economics and technologies is one of the subjects at school, where education for sustainable development is carried out. It is included in the general education curriculum.

It has ancient and constant traditions. That is confirmed by curriculum analysis and research. The aims and content of the subject have changed according to the development of economics and politics, as well as to the public opinion, traditions and everyday life.

Throughout the centuries, Home economics and technologies has proved its significance in the increasing the human life quality. Today the students' understanding about the safety and quality conditions of the human living environment, the ability to creatively involve and solve problems in sustainable development is emphasized in Home Economics (Lice, 2012). However, the human and his/her practical work was always in the centre. In the course of time also the name has changed Handicraft, Practical Work, Home Economics, Household, Work Training. The changes in education 
paradigms have affected this subject as well (Lice, 2003; Lice, 2012). Pupil's creative activity comes in the foreground. The development of the subject in Latvia is very similar to the development of the subject in Estonia (Taar, 2015).

Home economics and technologies deals with various topics related to sustainable development (Lice, Reihmane, 2015). One of those topics is „Handicraft”, that students learn from the first class. It is extensive, including item making from different materials, for example paper, carton, yarn, cloth, and technologies, for example gluing, folding, embroidery, braiding. Analysing the creative activity in Home economics and technologies of younger students, scientist E. Volane points out that younger students' creative activity is the creativity that is an original creation of the craft, which is a new approach in task solution in the process of knowledge and skills acquisition, in combining the methods of known activity (Volane, 2016). Starting the fifth form students choose the learning type of technology - textile technology or wood and metal technologies. They deepen their knowledge and improve their skills.

The teaching and learning process in handicraft lessons is being looked through the point of view of education for sustainable development. For example, the acquiring of different materials used in handicraft, rational usage of the materials, suitable technology accommodation for the design, secondary use of cuttings, leftover recycling, ecologic collection of unnecessary leftovers.

During handicraft lessons students make some kind of goods, obtaining skills and abilities in the performance of technologies, usage of materials, creation of design. An active cognitive process, mutual discussions, observations, experiments and comparison take place. Students work communicating with others and individually at the same time. That is why learning in Handicraft is organized in small groups. Describing teaching scientists K. Exley and R. Dennick (2004) point out that in a small group student can be encouraged to talk, think and share much more readily than in a large group. Communication is at the heart of small group teaching of any kind a crucial first step is the willingness of the students to speak to each other and to work together, improving one's individual good.

Presentation of pupil's individual work or group work as a learning method is popular in handicraft lessons. Scientist K. Egan (2010) stresses out that the presentation is an opportunity for students to share the results of their work and receive feedback on it from their peers and from others.

Purposefully organizing and managing a handicraft lesson, students obtain all the transversal skills emphasized by School 2030. Those are - self-examination and self-management, thinking and creativity, co-operation and participation, digital skills (Skola 2030, 2017, 8). Each pupil has a chance to learn handicraft more qualitatively with transversal skills from different education spheres. Whereas learning the specific features of handicraft, a pupil transfers his/her knowledge, obtained skills and learning methods to contexts of other subjects using transversal skills, in this way strengthening the bond between newly acquired knowledge and his/her personal experience and obtained skills.

Thus H. Janhonen-Abruquah, H. Posti-Ahokas and P. Palojoki (2017) indicate that all teachers should see the power of interdisciplinary cooperation, and Home Economics and technologies as a school subject (Handicraft as part in Home Economics and technologies) provides an excellent platform for this. Teachers are the main element in this process, which means that they must share information, negotiate, and be truly present in helping, designing, and enabling the implementation of good interdisciplinary practice.

Handicraft as a handmade product is a popular household object. Component parts of clothing and household object are made using different technologies. It is a laborious process which requires time, accuracy, knowledge. Today industrially made items outdo handicraft. The functions of handicraft have change during time. Once it was necessary for daily life. Nowadays an item made by handicraft is a special decorative product. Handicraft is acquiring another value compared to industrially made mass production goods.

Considering the change of education paradigm and new visions for education nowadays, deeper research of education content, its compliance with today's life, and the new person's career promotion is done. One of the researches is the research analysed in the article about handicraft. The aim of the research is to determine the students' attitude towards handicraft. 


\section{Methodology}

The scientific research was carried out in Jelgava (Latvia) during 2017. Students from four schools: Elementary School No.3, Elementary School No.4; State Gymnasium and Jelgava Spidola Gymnasium, took part in this investigation. Two hundred and fifty-five (255) respondents from classes 5 to 12 (aged 11-18) were invited to participate in this research. Three groups were formed according to the participant age. The first group A - respondents from classes 5 to 6 (105 participants); the second group B - classes 7 to 9 (90 participants); the third group $\mathrm{C}$ - classes 10 to 12 (60 participants). The research was carried out within lessons of Home Economics and Technologies (textile part). The research methods such as questionnaires and discussions were used in the current investigation. Each respondent group was analysed separately. The data was processed using the statistical data processing program SPSS for statistical analysis. The results have been summarized and the relevant ones are presented graphically using calculations of percentage.

Five questions connected with handicraft were included in the questionnaire revealing the students' attitude towards handicraft. Students chose one of the four given scales: yes; rather yes than no; rather no than yes; no. The question of the research - are there any differences in the attitude towards handicraft in different age groups.

\section{Results and Discussion}

The carried-out questionnaire about handicraft, discussions with students and the author's pedagogical experience helped to discover students' attitude towards handicraft. The results of the questionnaire show differences between respondent groups.

In everyday life handicraft products can be used differently: as components of clothing (e.g. gloves, socks, scarves, hats, cardigans, jumpers), as household objects (e.g. blankets, towels), as design objects (e.g. wall decorations, covers). The results of the questionnaire show (Figure 1) that respondents of group C (classes 10 to 12 ) mainly like to wear, use handicraft products (40\%), where as $34 \%$ of the respondents from group B (classes 7 to 8 ) and $27 \%$ of the respondents from group A (classes 5 to 6 ).

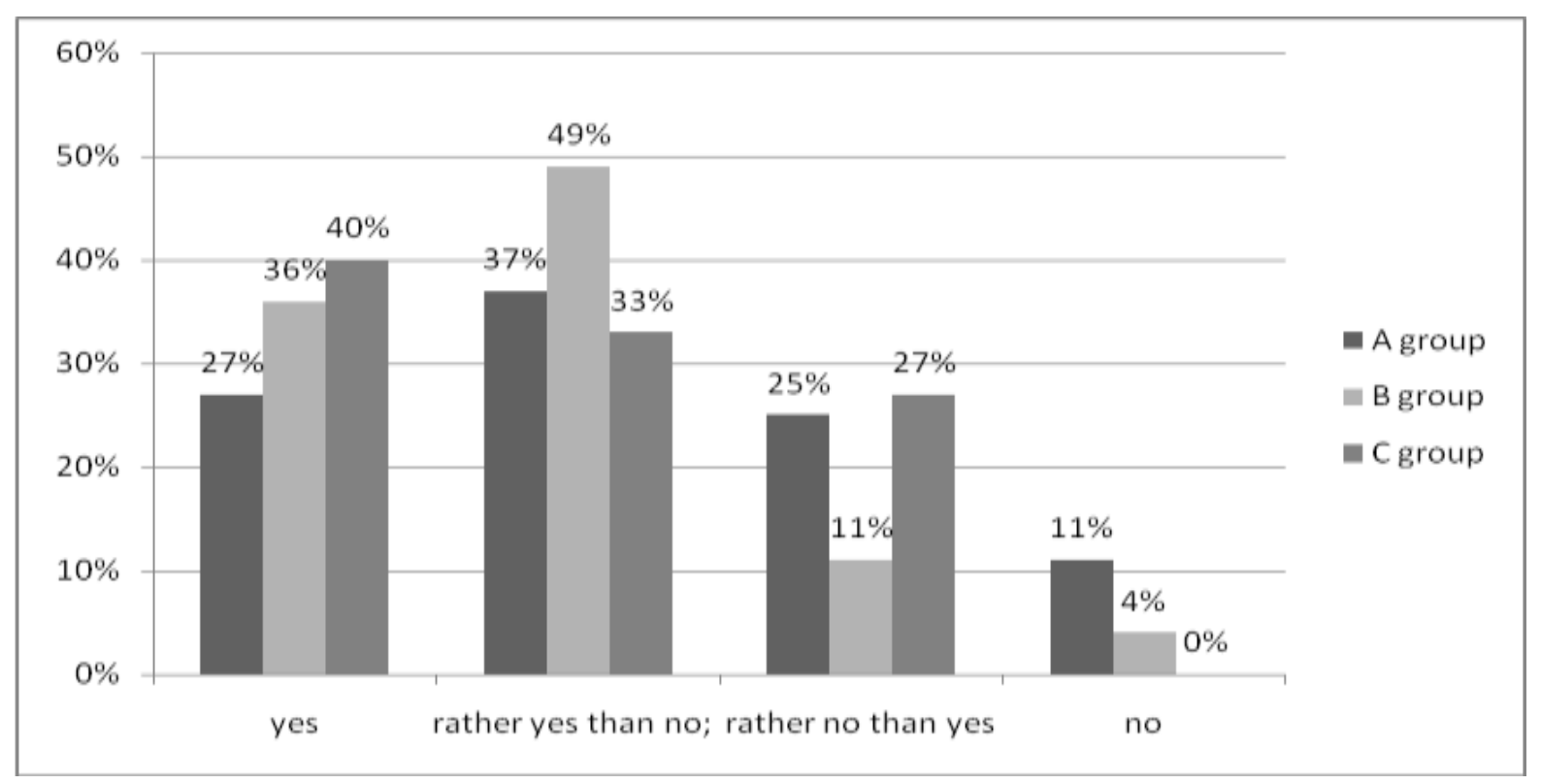

Figure 1. Handicraft product usage in everyday life.

Thirty three percent of the respondents from group C (classes 10 to 12), $49 \%$ of respondents from group B (classes 7 to 8 ) and $37 \%$ of the respondents from group A (classes 5 to 6 ) have indicated rather like than not like. Twenty seven percent of the respondents from group C, $11 \%$ from group B and $25 \%$ from group A have indicated rather not like than like. The author of the article is delighted that only $4 \%$ of the respondents from group B and $11 \%$ from group A don't like to use handicraft products.

Handicraft is a widely popular leisure activity for teenagers and adults. Students also like to make handicraft in their free time. But during Home Economics and technologies lessons all students make 
handicraft. They learn basic elements and use them in the making of a small work. The results of the questionnaire show (Figure 2) that the most of all respondents from group A (49\%) like to make handicraft goods within the lesson. Nearly a half less $-20 \%$ of the respondents from group B like to do it, but as for respondents from group $\mathrm{C}-33 \%$. Most of the respondents (34\%) from group A rather like than not like making by themselves, as for $25 \%$ of the respondents from group B and $27 \%$ from group C. Eleven percent of the respondents from group A, $33 \%$ from group B and $23 \%$ from group C have indicated that they rather not like than like. Six percent of the respondents from group A, $22 \%$ from group B and $17 \%$ from group C don't like making handicraft goods by themselves.

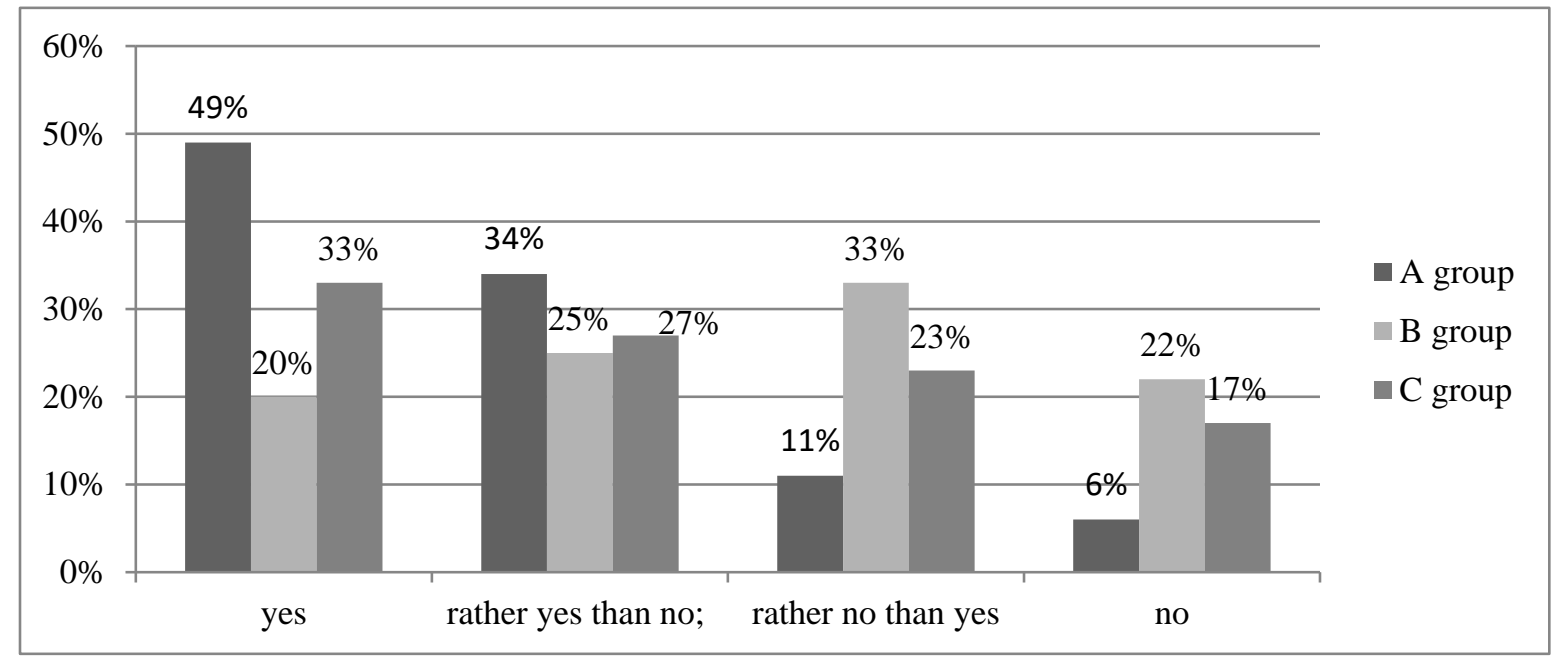

Figure 2. Delight of making handicraft goods.

Overall, it could be concluded that the respondents from all the groups rather like than not like doing handicraft. Eighty three percent of the respondents from group A, $45 \%$ from group B and $60 \%$ from group $\mathrm{C}$ have positive answers. It indicates that students like doing handicraft. The respondents from group B like doing handicraft the least $-22 \%$ have answered definitely no. The respondents from group A like doing handicrafts the most - only $6 \%$ do not like it.

Family is the first environment where a child learns life skills, feels love, respect and excepts values. Handicraft as hand work is a value. There are people to whom it means a lot. Families respect national traditions, praise the doer's honour, teach respect to work.

The questionnaire results show (Figure 3) that handicraft is respected in families.

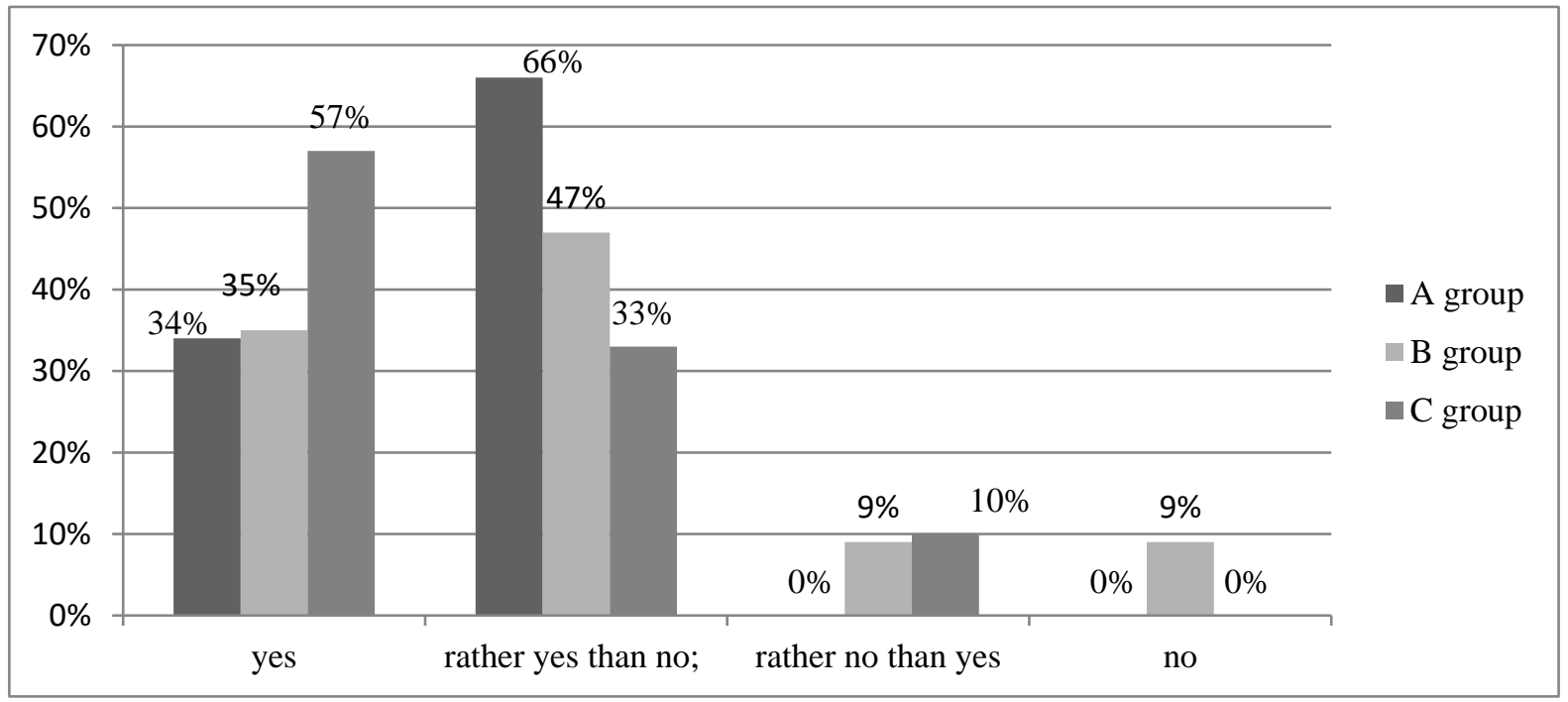

Figure 3. The attitude towards handicraft in a family.

The families of respondents of group C highly respect handicraft (57\%), respect handicraft (33\%). The families of respondents of group B highly respect handicraft (35\%), respect handicraft $(47 \%)$. The families of respondents of group A highly respect handicraft (34\%) and respect handicraft (66\%). 
Only $9 \%$ of respondents from group B have indicated that they are not interested in handicraft at all, but $9 \%$ from group B and $10 \%$ from group $\mathrm{C}$ are indifferent to it.

The results of the questionnaire show (Figure 4) that according to the self-evaluation the highest evaluation - highly respect - were given by $43 \%$ of the respondents from group C, $31 \%$ from group A, and $25 \%$ from group B. Fifty three percent of the respondents from group B, $52 \%$ from group A, and $43 \%$ from group $\mathrm{C}$ have chosen the answer respect. Seventeen percent of the respondents from group A, $13 \%$ from group B and $9 \%$ from group $\mathrm{C}$ have chosen the answer indifferent. It can be concluded that the majority of the respondents have pointed out that they highly respect or respect handicraft.

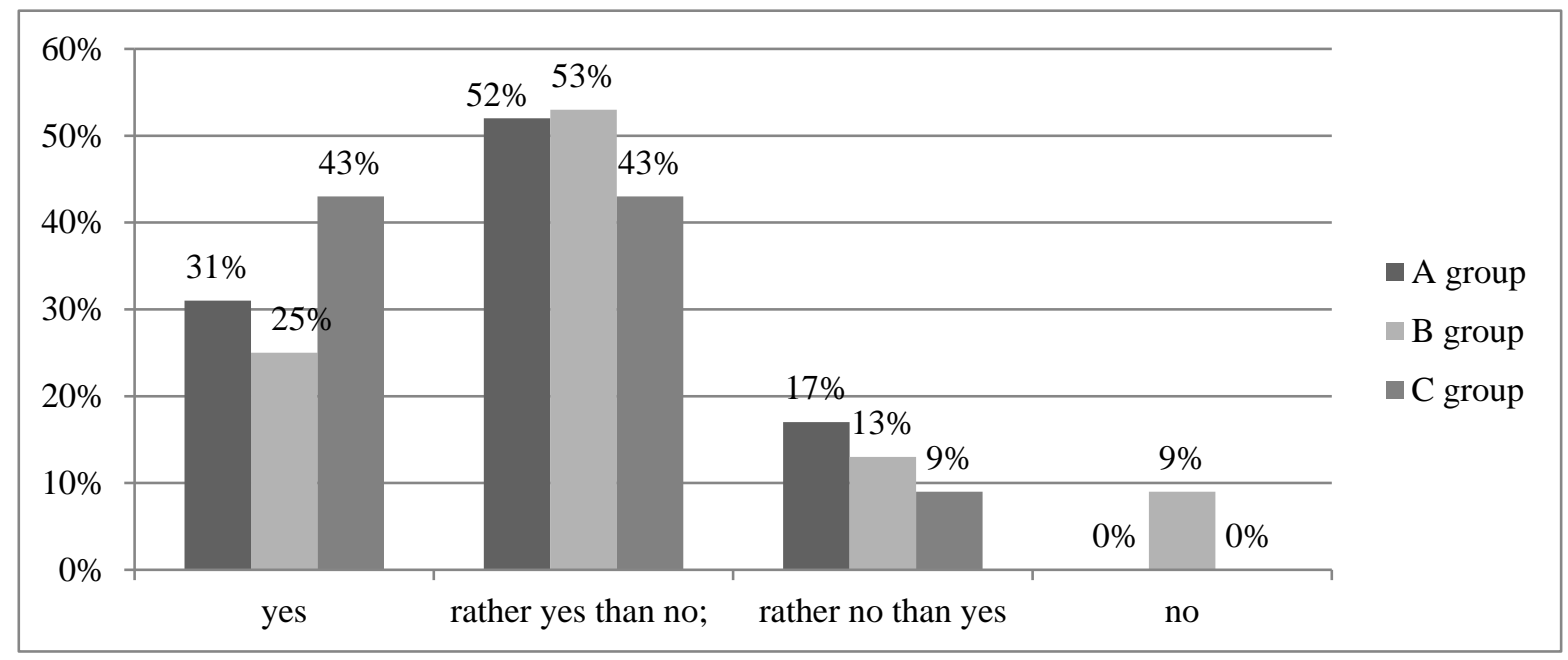

Figure 4. Self-evaluation of handicraft.

The most important is that teaching at school is deliberate and systematic and it is not regulated by students' interests but by curriculum worked out by experts not personally acquainted with teachers. As a result, the subjects taught at school are often not connected with the children's interests in the learning process, and possibilities which should be provided at school are not used (Wells, 2004).

Handicraft is one of the themes that are included in contemporary content of the Home Economics and technologies curriculum. The question about including handicraft theme in the comprehensive school is actual nowadays from different points of view. That is why the pupil's thoughts about including handicraft in the curriculum are important.

The results of the questionnaire convincingly show (Figure 5) that the theme Handicraft must be included in the curriculum.

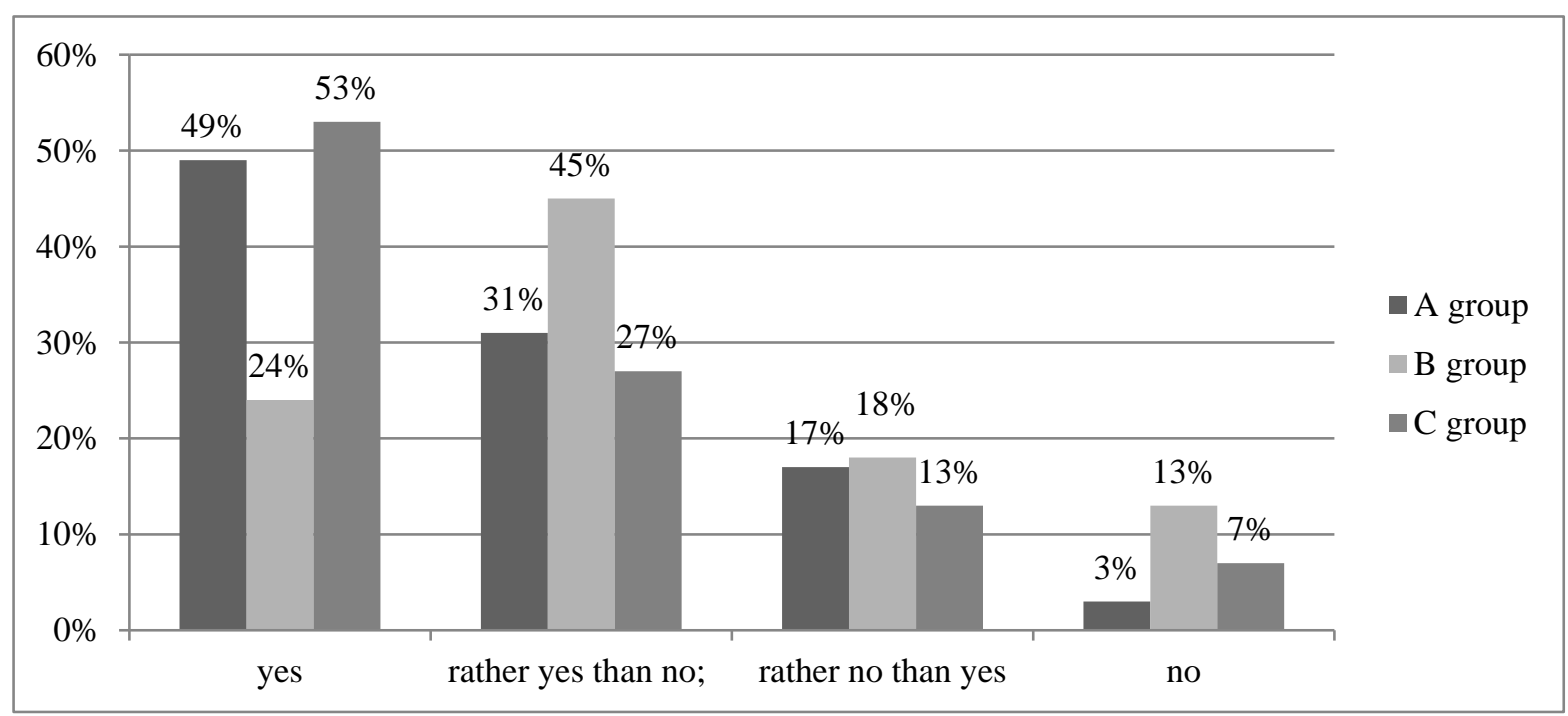

Figure 5. Handcrafts as the theme in the Home Economics and technologies. 
It is shown by the majority of the respondents from all the groups. Overall it is mostly accentuated by the respondents from groups A and C (80\%, of which group A - yes $49 \%$, rather yes than no $31 \%$; group C yes $53 \%$, rather yes than no $27 \%$ ). The respondents from group B $69 \%$ (accordingly $24 \%$ and $45 \%$ ).

Most B group respondents - thirty one percent (no $13 \%$, rather no than yes $18 \%$ ) are against the including of handicraft in the curriculum. The respondents from group A $(20 \%)$ and group C (20\%) are also against it (accordingly group $\mathrm{A}-$ no $3 \%$, rather no than yes $17 \%$; group $\mathrm{C}-$ no $7 \%$, rather no than yes $13 \%$ ).

The author is surprised about such results. The author during her multiannual professional career and teaching practice has observed that students learn handicraft technologies with more and more difficulties. Discussions with the students show their wish to learn the techniques, to make not complicated but simple works.

\section{Conclusions}

- The change of paradigm in education also involves change of values. The changes in education paradigms have affected also subject Home Economics and technologies. One of those topics is „Handicraft”. The teaching and learning process in Handicraft lessons is being looked through the point of view of education for sustainable development.

- There are differences in the attitude towards handicraft in different age groups. The respondents from all the groups rather like than not like using handicraft. Sixty four percent $64 \%$ of the respondents from group A, $73 \%$ from group C and $85 \%$ from group B have positive answers. It indicates that pupils like using handicraft.

- The respondents from all the groups rather like than not like doing handicraft. $83 \%$ of the respondents from group A, $45 \%$ from group B and $60 \%$ from group $C$ have positive answers. It indicates that pupils like doing handicraft. The respondents from group B like doing handicraft the least $-22 \%$ have answered definitely no. The respondents from group A like doing handicrafts the most - only $6 \%$ do not like it.

- Handicraft is highly respected and respected in families. It was pointed out by $100 \%$ of respondents from group A, eighty two percent $(35 \%+47 \%$ ) from group B and $90 \%$ from group C. Only $18 \%$ of the respondents from group B and $10 \%$ from group C are indifferent and not interested at all in handicraft.

- The majority of the respondents have pointed out that they highly respect or respect handicraft. The results of the questionnaire convincingly show that the theme Handicraft must be included in the curriculum. It is shown by the majority of the respondents from all the groups. Overall it is mostly accentuated by the respondents from groups A and C (80\%).

- Discussions with the students show their wish to learn the techniques, to make not complicated but simple works. The students could also see generation traditions and values through handicraft. They also evaluated the moral aspect obtained from handicraft

\section{Bibliography}

1. Commission of the European Communities. (2008). Improving Competences for the 21 st Century: An Agenda for European Cooperation on Schools. Retrieved from http://eurlex.europa.eu/LexUriServ/LexUriServ.do?uri=COM:2008:0425:FIN:EN:PDF

2. Egan K. (2010). Learning in Depth: a simple innovation that can transform schooling. Chicago: The University of Chicago Press, Ltd.

3. Exley K., Dennick R. (2004). Small Group Teaching: Tutorials, Seminars and Beyond. London: Routledge Falmer.

4. Janhonen-Abruquah H., Posti-Ahokas H., Palojoki P. (2017). Teaching and learning in Home Economics education. International Journal of Home Economics, 10 (2), 4-5.

5. Lice I. (2003). Historical Development of the Subject Home economics at General Education Schools in Latvia. In B. Briede (Ed.), The Proceedings of the International Scientific Conference Rural Environment. Education. Personality,4. Jelgava: LLU, TF, 126-131. 
6. Lice I. (2012). Change of direction of Home Economics subject. In V. Dislere (Ed.), The Proceeding of the International Scientific Conference Rural Environment. Education. Personality, 5. Jelgava: LLU, TF, 241-248. Retrieved from http://llufb.llu.lv/conference/REEP/2012/REEP2012-proceedings-E-ISSN-2255-808X.pdf

7. Lice I., Reihmane S. (2015). Education for Sustainable Development at Home Economics. In V. Dislere (Ed.), The Proceedings of the International Scientific Conference Rural Environment. Education. Personality (REEP), 8. Jelgava: LLU, TF, 230-236. Retrieved from http://lufb.llu.lv/conference/REEP/2015/Latvia-Univ-Agricult-REEP-2015proceedings-230-236.pdf

8. Skola 2030 (School 2030). (2017). Izglitiba musdienigai lietpratibai: macibu satura pieejas apraksts (Education for modern competence: the description of approach for education content). Riga: IZM, ESF. Retrieved from

https://domaundari.lv/cepure/Macibu\%20satura\%20un\%20pieejas\%20apraksts.pdf (in Latvian)

9. Sustainable Development Strategy of Latvia until 2030. (2010). Riga: Saeima of the Republic of Latvia. Retrieved from

http://www.varam.gov.lv/in_site/tools/download.php?file=files/text/dokumenti/pol_doc//LIAS_2030_en.pdf

10. Taar J. (2015). Home Economics Curricula in Estonia. In H. Janhonen-Abruquah, P. Palojoki (Eds.), Creative and Responsible Home Economics Education. Helsinki: Helsingin yliopisto, 164-175.

11. UNESCO. (2014). Education Strategy 2014-2021. Retrieved from http://unesdoc.unesco.org/images/0023/002312/231288e.pdf

12. Volane E. (2016). Pupils' Creative Action at an Elementary School: Problems and Solutions. In V. Dislere (Ed.), The Proceedings of the International Scientific Conference Rural Environment. Education. Personality (REEP), 9. Jelgava: LLU, TF, 195-201. Retrieved from http://llufb.llu.lv/conference/REEP/2016/Latvia-Univ-Agricult-REEP-2016proceed2255-808X195-201.pdf

13. Wells G. (2004). The Role of Activity in Development and Education. Journal for the Study of Education and Development, 27(2), 165-187. 